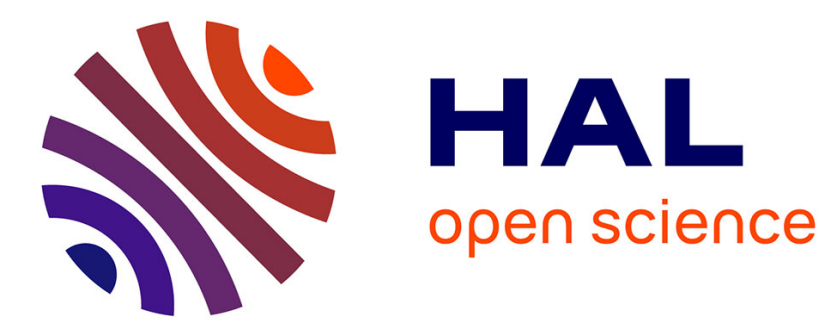

\title{
Users and uses of the biopolitics of consent: a study of DNA banks.
}

\author{
Pascal Ducournau, Anne Cambon-Thomsen
}

\section{To cite this version:}

Pascal Ducournau, Anne Cambon-Thomsen. Users and uses of the biopolitics of consent: a study of DNA banks.. The Ethics of Research Biobanking, Springer US, p. 33-48, 2009. halshs-00490789

\section{HAL Id: halshs-00490789 \\ https://shs.hal.science/halshs-00490789}

Submitted on 9 Jun 2010

HAL is a multi-disciplinary open access archive for the deposit and dissemination of scientific research documents, whether they are published or not. The documents may come from teaching and research institutions in France or abroad, or from public or private research centers.
L'archive ouverte pluridisciplinaire HAL, est destinée au dépôt et à la diffusion de documents scientifiques de niveau recherche, publiés ou non, émanant des établissements d'enseignement et de recherche français ou étrangers, des laboratoires publics ou privés. 


\title{
3. Users and uses of the biopolitics of consent: a study of DNA banks
}

\author{
Pascal Ducournau, Anne Cambon-Thomsen
}

\begin{abstract}
:
In this chapter we intend to examine from a sociological perspective the view of a number of participants in a biobank project on the informed consent procedure they were asked to go through. Having carried out observations, conducted interviews and collected questionnaires as part of an empirical survey, we have concluded that a number of participants feel somewhat suspicious where the procedure is concerned. At least they express caution on its ability to actually serve their autonomy and freedom of choice. As they attempt to detect its potentially perverse effects in terms of power asymmetry and the consequences of diverse responsibilities being devolved to them, their perception of it is far from idealized even if they do not contest it radically. This circumambulatory tour of the users' point of view, which will prove useful to improve communication with the general public, can also be of help in understanding how the contemporary evolutions of biopolitics are perceived.
\end{abstract}

\section{Introduction}

In light of the contemporary evolution of health management systems run by states or medical institutions, it has been widely observed that a new approach in managing public health has emerged: there is greater emphasis on education, consensus and seeking the consent of individuals and populations. This trend is what Foucault called 'biopolitics', and one of its main characteristics is to encourage individuals to exercise self-control over behaviour that might affect their health, and over how they make use of the body and its constituent parts, rather than to resort to direct constraints or impose sanitary obligations and health rules: proactive prevention policies, community health initiatives, health education, coaching and patient counselling, gathering informed consent of individuals in various situations (medical acts, medical research, donations of biological substances: gametes, bone marrow, DNA, etc).

The concept of biopolitics was first coined by Foucault in order to describe the advent, in the course of the $18^{\text {th }}$ century, of a mighty shift in the exercise of power, from conquest and ruling over people's lives to a political technology aimed at fostering life and boosting its yield (Foucault 1976). The exercise of power, which had been exclusively grounded in the right to take lives (bringing death upon some and allowing others to live), as reflected by the lords and monarchs who disposed of the lives of their subjects for their defence (in time of war or an attempt against their person, etc), slowly evolved into a form of power that no longer 'let live' but 'gave life' through multiple initiatives aimed at managing, increasing, multiplying, exercising control over and 
applying regulations to life at an individual as well as a populational level. Such concern for life led to the development of a dual control system:

- on the one hand a growing number of disciplines to be exercised on the human body in order to expand its abilities, draw out its strength, increase its docility;

- on the other hand the introduction of the concept of 'populational biopolitics', centred on the body as a representative of the species, and designed to pace and monitor the biological processes which affect the population at large, such as births and deaths, states of health and life spans.

The implementation of this biopolicy has produced new elements of knowledge and new practices that are at the core of the modern state, such as demography, hygiene, urbanism and public health. The state must now 'take charge of the 'bodies', no longer in order to claim rights over their lives or protect them against the enemy, nor simply to exercise punishments or extort taxes, but to help them, and maybe even to compel them to preserve/ take care of their health. The obligation to stay healthy is both everyone's duty and the general goal (Foucault 1994:16).

Several observers in the 'post-Foucault' line of thinking have been struck by the connection between the historic shift described in his works and the many initiatives that have been taken recently to obtain the support, consent or consensus of the population regarding the management of their health and their bodies. According to Dozon (2001), these measures show that a new public health paradigm is emerging, one no longer based on constraints but on a contract. Alternatively, they could mark the advent of a new bodymonitoring system that goes together with the fading away of disciplines, 'corporeal liberalism' and an 'individualized or delegated biopolicy' (Memmi 2001, 2003). Without indulging in a fairy-tale vision of the new paradigm of health and body management, the existing literature has also stressed that it entails the potential occurrence of complex power relations. Dozon notes that the constraint paradigm is always likely to resurge. Memmi in turn remarks that the ideal form of government, based on the self-control which patients exercise over their biological destiny, often conceals, between the latter and their doctors, "objective power imbalances such as the unequal availability of information, technical knowledge and language skills, which leave the patient with no other option than to give in to the requests of medical professionals" (Memmi 2003: 303304). On a different note, Berlivet (2003) draws attention to the quite paradoxical manner in which modern-day prevention schemes are presented to individuals: it appears that, while no longer 'blaming the victims' and while seeking freedom from addiction and social pressure which typically induce risky behaviour, prevention and health education schemes lead the targeted individuals to adopt pre-set identities that they are expected to identify with (the 'non-smoker', the 'moderate drinker' etc). The mode of subjectification which emerges is bipolar: subjugation and empowerment. Following these studies on the paradoxical nature of the new enforcement tools for health policies, it has been suggested (Martucelli 2003) that all contemporary initiatives concerning prevention (against cancer, cardio-vascular diseases, HIV, etc) coincided with the development of a modern form of domination based on making individuals liable for their health. Domination traditionally relied on the concept of dependence. However, contemporary forms of domination encourage subjects to become active. In doing so, they prompt them to take on a number of responsibilities that have been devolved to them. Through this devolution of responsibilities, the actors are not expected to abide by a set of norms. Instead they are 
instructed to face facts that are presented as being the logical and unavoidable consequences of their actions, past or present. To sum up, "it is less a matter of dictating what needs to be done than to get individuals to realize that they are the 'authors' of their own lives" (Martucelli 2003: 491) and, more importantly, the 'authors' of the consequences of their actions.

This brief look at the existing critical literature provides an overview of the subject, and gives reasons to believe that we are currently witnessing a subtle refinement of power relations in the field of biopolitics. Power has acquired the ability to renew itself through the subjectivity of the actors, to further interfere with their desires, choices and actions, even to be heard through the assertion of the ego. But are the actors truly being deceived by the new configuration of power relations? Could the case be that the implementation of this sort of power relations, based on an original acceptance of constraints and the individualization of the latter, is taking place without the individuals concerned (the publics targeted through prevention campaigns, users of health institutions, patients) knowing and in a manner so inconspicuous that they are bound to adhere to it without formulating any criticism? This question deserves careful consideration as two diverging versions of the modern forms of domination can be derived from its answer: one would set forth its imperative, unavoidable dimension, and the other would expose its relative nature, one potentially superseded by the interplay of the actors, who might use their skills to keep it at bay, not letting it influence their behaviour. The second alternative could bring back the notion that the actors always have the possibility of calling into play the 'quant-à-soi' (keeping to oneself) in the new context of developing a biopolicy which, it seems, no longer has anything in common with the era of disciplines described by Foucault.

\section{Field approach and method}

The opinions of the actors who most openly welcome the modern-day health and medical mechanisms set up by health institutions provide a privileged empirical starting-point to answer the question raised. They enable us to approach the topic from a perspective which a priori rules out the 'quant-à-soi' or ability to keep oneself at a distance, bypass, become aware of or keep at bay the forms of domination that might accompany the implementation of these mechanisms. We compiled empirical data collected through a survey based on ethnographic observation, interviews and questionnaires involving individuals who agreed to participate in a DNA bank within the framework of an epidemiological survey, using a procedure designed to gather their free and informed consent as required by the existing judicial and ethical norms.

This epidemiological survey was based on a comparison between one 'case group' and one group of 'control subjects', and was intended to assess the prevalence of cardio-vascular pathologies among the 'general population', to carry out a follow-up and to identify the risk and protection factors - both genetic and environmental - of the said pathologies. The originality of this survey consisted in the creation of a DNA bank, which concerned the 'general population' as well as a sample population recruited in a hospital. In total about 1800 individuals - exclusively men aged between 45 and 75, i.e. an age group being considered most 'at risk' for coronary and vascular diseases - were recruited in southern France by a laboratory belonging to the Institut National de la Santé et de la Recherche Médicale (Inserm) to participate in the study. 
The creation and expansion of DNA banks during the last decade has triggered a prolific output of normative and speculative texts ${ }^{21}$ about their stakes and the manner in which they should be set up, governed and used. It is worth noting that these texts often put emphasis on the definition of and respect for the rule of informed consent as a fundamental, sine qua non condition for the realization of DNA bank projects. Thus, a kind of transnational consensus in favour of the application of this rule has emerged, while biobank projects not complying with this rule have been met with harsh criticism both in the specialized press and in the mass media. DNA banks constitute therefore a selected platform for expressing the modern forms of biopolitics. So, to repeat the expression coined by Memmi, we are looking at the implementation of an 'individualized or delegated biopolicy' linked to DNA bank projects. Individuals are prompted, in a way that is undoubtedly new and unprecedented, to exercise through the rule of informed consent control over what can and cannot be done with the constituent parts of their bodies.

Thus, the proactive involvement of citizens is vested in this rule, which might become the keeper of sound judgment against the dangers of human genome research (Caze de Montgolfier 2002). "Giving participants the opportunity and freedom to participate in a research protocol puts researchers under the obligation to respect their choices" (Caze de Montgolfier 2002: 67). Or, as specified in one of the recommendations of the Human Genome Organisation dating back to 1996 (HUGO-ELSI 1996):

"The HUGO-ELSI Committee recommends [...] that any choices made by participants with regard to storage or other uses of materials or information taken or derived therefrom be respected. Choices to be informed or not with regard to results or incidental findings should also be respected. Such choices bind other researchers and laboratories. In this way, personal, cultural, and community values can be respected".

This recommendation originates from a time period - the $1990 \mathrm{~s}$ - which was marked by controversies about informed consent, with certain actors claiming that "a hijacking of the concept of informed consent" was to be feared leading to the use of DNA samples and the associated medical and social background data for purposes that were not specified at the beginning of the research, or to a commercial use of genetic sample banks (Bungener et al. 2002). The fear of such 'hijackings' has given rise to an 'era of suspicion' around DNA banks, which the press has pointed out over the past few years. The fear associated with the use of genetic data to analyze behaviour in a strictly biological way (violence, homosexuality, alcoholism, schizophrenia etc) has contributed to stressing the importance of describing the medical and scientific aims of genetic research projects when seeking the participants' consent. It is hoped that keeping the public informed will make it possible to achieve the respect of 'personal, cultural and community values'.

In current practice, the application of the concept of informed consent encapsulated in the protocol for the establishment of DNA banks is meant to put the individual participating in a research project in a position of 'informed decision-maker'. Consequently the informed consent procedure must provide clear guidelines for the

${ }^{21}$ For this, see review in Cambon-Thomsen et al. 2007. 
biomedical actors involved in the protocol as well as for the individuals recruited, through the following sequence of actions:

- information must be provided to the subject by the research team in the form of an explanatory note and through oral communication;

- the team must strive to make the written and oral explanations as clear as they possibly can so as to ensure correct understanding on the part of the individual concerned.

The physician is formally requested to evaluate the subject's understanding of the project, and to encourage them to ask any questions that might be relevant. The subject is then asked to sign a consent form indicating that his or her decision to participate in the project is informed and free. This procedure was carefully followed with regard to the DNA bank that we observed. We were given the opportunity to observe how the participants' consent was gathered over the three years during which the project was carried out. At the same time we assembled a collection of quantitative data using a questionnaire filled out by the physician who interviewed the participants. In the questionnaire the physician documented items regarding the interview, indicated if the participants had asked questions and whether or not they had signed the informed consent form after having read it. The physician was also asked to give to each participant another questionnaire asking for the reasons why they had chosen to take part in the study. We also carried out about sixty interviews with individuals participating in the study in the days following their inclusion, some of whom were known to us as we had observed their interactions with the physician. These interviews were meant to examine more closely the reasons for their participation, to analyze the account of the events which led the subject to agree to participate in the project, the meeting with the physician and the procedure of informed consent. The observations were performed with an ethnographic methodology. The analysis was both qualitative and quantitative. Interviews were recorded, transcribed and submitted to qualitative textual analysis of content; answers to questionnaires were statistically analysed in univariate analysis. The results described below allowed deriving a typology of interactions related to informed consent.

\section{Types of physician-subject interactions observed.}

We were able to identify five main types of interaction between the recruiting physician and the subjects whose consent for participation was targeted. We only had the opportunity to carry out these observations in a systematic manner on the group of 'control subjects'. These individuals were sent a letter asking them to participate in the creation of the DNA bank and were offered a check-up on their level of risk for cardiovascular diseases (they were not given the test results pertaining to their genetic characteristics). The potential participants were invited to go to a health centre for a blood test, undergo a number of medical examinations (electrocardiogram, doppler, body fat measurement), and fill out a questionnaire about their lifestyle and their medical history.

The group of subjects recruited in a hospital setting was more difficult to approach. Although we found it relatively easy to carry out interviews with them after their inclusion in the protocol, we could only observe in situ the admission into the research protocol of a very limited number of cases (hardly a dozen), not enough for the data collected to reach an adequate level of information saturation. 
During the inclusion procedure, the informed consent form that the participants were expected to sign was placed by the physician on the desk, on the side where the participant was supposed to sit. The form was thus clearly displayed and put apart from any other documents lying on the desk (labels, questionnaires, cards filled out by the physician etc). The form repeated the main topics from the explanatory note previously provided to the patient, to which he had already given his preliminary consent. It included two or three additional items for which the participant had to indicate if he agreed to

- participation in a study on coronary diseases,

- participation in the creation of a DNA bank by giving a blood sample,

- willingness to be interviewed about his experience as a participant

Our own survey was thus included in the very procedure of informed consent, following the intention expressed by the physician in charge of the DNA bank project to declare the sociological survey to an ethics committee and to include it in the ethical framework of the project itself.

The formulas used by the physician to present the form were usually quite repetitive: after going through a short oral presentation of the study, which sums up the explanatory note previously sent by surface mail, the physician asked the participant to "read the document, sign it and feel free to ask questions if anything remains unclear". Most of the time, at this point, the physician took the form from the subject and signed his name in the intended space before he gave it back to them.

The first type of interaction occurred in relation to the consent form itself. That is, the form as such did not seem to play a prominent part in the exchanges between the physician and the participant, in the sense that none of them made particular use of it. Obviously, it was eventually signed by the participant, but this did not require any question-response interplay, nor did it trigger any remark from one or the other. The participant signed the document without uttering a word. The most direct way of neglecting the 'consent form' consisted in adding the signature automatically without reading it first.

The second type of interaction was characterized by a greater significance being accorded to the signing procedure. The presentation of the consent form prompted a certain number of participants to consider it and read it, sometimes with great attention. The form then became a useful aid for discussing the conditions of participation in the project. More than a simple aid for discussion, this procedure could therefore be perceived as a third party which provided the participants in the DNA bank project with a coherent framework for ethical decision making and the reduction of uncertainty.

The third type of interaction that emerged did not result in a reduction of uncertainty through the exchanges that the form brought about. On the contrary, it resulted in a significant increase of uncertainty. In those cases the procedure was not called upon to expose the goals and modes of operation of the study or the uses of the DNA bank. The procedure of informed consent was instead perceived as a judicial device aimed at concealing something ("Why do I have to sign? Are there any risks?" one of the participants asked). The dialogue then revolved around the potential risks that the participants thought they might be exposed to if they gave their consent to the study: "Are you going to put me under the knife to get my DNA? [...]. Then why should I have to sign? I don't even know where you want to take me to..." Questions were also raised 
about the use that could be made of the genetic samples. "I hope you're not going to make GMOs or stuff like that, are you?"

As an extension of the third pattern of interaction, the fourth type exposes what could be interpreted as a 'game of non-commitment' on the part of the participant, who ticked the items but did not sign the form, or signed it but failed to fill it out thoroughly. In such situations, the participants did not exactly refuse to sign or fill out the consent form but, faced with a situation which they seemed to perceive as uncertain and risky, they brought into play what we might call 'avoidance tactics'. "The surest way of averting danger is to avoid encounters where it might arise" (Goffman 1974: 17).

Finally, the last pattern we observed arose when the participants argued that their word was as good a guarantee for their commitment to participate in the study as their written consent. This pattern could be interpreted as the sign of a clash between two conflicting modes of trust, one based on a written document and the other on the 'given word'. Some of the remarks these participants made lead us to believe that they perceived the procedure as a sign of mistrust of them and of the genuineness of their commitment to the project.

Judging from the five types of interaction described above, it appears that the procedure of consent is not self-evident or commonly accepted. It may generate distrust or different forms of 'avoidance', induce tensions in the interactions between the participants and the physician and even be openly criticized by the former. These observations show what could appear to be a certain form of distrust on the part of the participants towards a possible transfer of responsibilities which they see as the consequence of having added their signature to formalize their consent. The responsibility involved could cover several aspects: obviously, a judicial and administrative aspect is involved, even though the wording on the consent form clearly states that giving one's consent in no way exempts the researchers and medical doctors involved in the study from their responsibilities. But a moral aspect is also involved, since the request for a signature seems to be perceived as the sign that the medical personnel question the genuineness of the participant's commitment. These observations seem to point out that the frames of perception of the actors have reached a raised level of awareness intended to detect a potential power asymmetry that could be the result of a system which grants them greater autonomy and protection. From a quantitative point of view, the patterns of interaction which indicated that these situations were likely to arise (the third, fourth and fifth type) were not in the majority compared to the more common situations which, on the contrary, seemed to show a lack of awareness (the cases where the signature was added in silence, without reading the explanatory note first or apparently without arising mistrust).

\section{Consent as seen by its 'subjects'}

The interviews that we carried out with the participants in the days following their inclusion in the research protocol shed light on the patterns of interaction that we have briefly described above, as they gave us the opportunity to record their account of their participation in the informed consent procedure, and consequently their points of view. These interviews show that, even though in the majority of cases the procedure was not truly condemned, the participants had not necessarily felt compelled to adhere to it wholeheartedly, even in the case of those who had signed the consent form without any 
apparent hesitation. Surprisingly, the way consent is perceived by the 'subjects' exposes a set of relatively systematized perceptions - and even points of view - that contradict a number of statements pertaining to medical ethics in general, and to the constitution of biobanks in particular. Notably these perceptions highlight the 'ambiguous', paradoxical nature of the informed consent procedure since, in the eyes of some, it grants individuals a much greater autonomy, when for others it induces heteronomy in the relations between individuals and the medical profession. Thus, far from developing a fairy-tale vision of the biopolitics of consent, the points of view that we recorded point to the fact that biopolitics might also carry elements of constraint and power that are relatively unforeseen. They appear all the more insidious as they are embedded in procedures with the objective to expand the subject's autonomy.

\section{Responsibilities}

The relatively high incidence of interaction patterns characterized by the absence of questions about the study on the part of the participant, or by the fact that a considerable number of them added their signature without reading the consent form, can partly be explained by the trust factor. The interpretation of a bond based on trust generally falls under one of two types of analysis: one highlights the fact that trust is an act of selfgiving and submission to the power of another individual, and the other emphasizes that the trust manifested by a partner always implies the opening of a debt that must be paid off through some form of reciprocity. ${ }^{22}$ Obviously the second alternative does not exclude the possibility of there being an unbalanced relationship between the two partners. However, when giving their trust, individuals put the recipients in a position where they have to comply with a moral obligation. It is precisely this obligation that certain participants call upon in their accounts, as we observed in the course of the interviews. The participants are encouraged to take an interest in the information provided to them, to read the explanatory note and to eventually make what may be described as an enlightened decision; yet, on the one hand, they feel incapable of acting in an 'informed' manner, and on the other hand they express the trust they have invested in the medical actors. This indicates that there is, in practice as well as in theory, a profound gap between participants and a procedure that is intended to empower them to act as informed and autonomous subjects.

Although according to the accounts of certain participants, there is no way of knowing whether the DNA samples will be used in accordance with the existing

\footnotetext{
${ }^{22}$ As Karpik notes quoting Benveniste (1969), the relation of trust is an indication of an existing relation of exchange governed by the rule of reciprocity: "one who receives trust is in fact granted an open line of credit by his partner, and therefore his partner holds a letter of credit so the debt can only be cancelled by an equally important compensation in the form of protection or guarantee (Karpik 1996: 528). Furthermore, the relation of exchange is also grounded in unequal conditions, as shown by the secondary meaning of fides (credit or trust): "putting one's fides in another person brought in return their guarantee and their support. But this very notion clearly shows that the conditions are not equal. Therefore there appears to be a power of authority that is exercised concurrently with a power of protection over the individuals that submit to it in exchange for their submission and as far as it extends. This relation implies the existence of a power of constraint on the one hand, and obedience on the other hand." (Benveniste 1969: 118-119).
} 
legislation or will serve ethically 'condemnable' purposes ("anyway if they want to do cloning they aren't going to tell us, so there is no way we can find out, and it's not even worth asking because they are not going to tell us") the relation of trust called upon by the participants places the biomedical actors in a situation of holding a moral debt that they must pay off since failing to do so will bring about 'punishment', and this is where we find one of the first attempts at describing the question of responsibility:

"I don't give a damn about knowing what this research is about. It takes too long to read [the explanatory note]. [...] Anyway I asked if I was going to feel discomfort or something, of course. That's what I want to know about. If I had been asked to take drugs and come back every month, well, I might have disagreed with that [...]; I don't intend to go and find out if what I think about genetics is true or completely wrong. There are doctors, I say, that's what they're here for. Then it all depends on whether you want to trust them or not. [...] If you want to be informed you're wasting your time, it's no use. [...] See, I'm a good participant, I don't ask questions [...]. I gave what I had to give. Now [it's up to] the doctors, [the] researchers, to do the rest. And I trust them to do what's right. If they put it to a bad use, God will punish them, and then the devil will burn their feet. That's just a way of describing it, but it's what it comes down to, really." (Int. $\mathrm{n}^{\circ} 35,2^{\text {nd }}$ age bracket, case subject)

This sort of account contradicts a number of studies carried out in the field of medical ethics - quite often by physicians - that conclude that the state of ignorance of the participants in the study is directly linked to their lack of information. According to these studies, this lack of information is a result of either the elements provided being intentionally partial, or their formulation being inappropriate and incomprehensible for the lay public (Moutel 2003). The ignorance of the participants may also be voluntary (Michael 1996) and associated with a concept of responsibility (of a medical, ethical and moral kind) that should be ascribed to the medical actors. Applying these parameters to the question of responsibility also contradicts all the ethical declarations mentioned in our introduction that intend to turn the biopolitics of informed consent into the keeper of the contemporary regulation system for the development and uses of gene technology.

It may be worth noting that the concept of responsibility invoked by some of the participants we interviewed carries within itself, albeit in an implicit and popularized form, the elements that provide the basis for a contemporary theoretical and critical approach of those insitutionalized procedures which value the involvement and participation of citizens. So the attempts made to avert the dangers associated with the potential disengagement of the authorities and the medical institutions really have enabled researchers to identify certain risks of misuse posed by the act of delegating responsibility to citizens through their involvement in decisions concerning health or biomedical research in the general sense (Polton 2000), and more particularly within the framework of the advances in gene technology (Moulin 2000).

Even more explicitly, some of the accounts collected from participants set forth their perception of the intrinsically ambiguous nature of the informed consent procedure. The following remarks were formulated by another participant, who expressed his 
concern about the use that might be made of the DNA sample, and about the uncertainties that lie heavily over the human genome research at large:

" 'Informed', that would mean having the maximum, knowing the real objectives of the experiment, and all the ins and outs, what it is really for, what act is going to be performed... it sounds ambiguous to me! Because practically speaking what do we know about their intentions? [...] If there is a hidden agenda, at least my intention is not to manufacture weapons or ways to oppress the people. If they [the actors of the DNA bank project] use it to make a diabolical weapon, I don't know but anyway, come to think of it, it's not my responsibility. [...] Whatever can be done with this knowledge, it doesn't belong to me... So OK to do the research, but then again, the applications may not be too good! Einstein worked on relativity, but hey, what did Oppenheimer do with it... So we do research... but again, when you think about it, it's the responsibility of whoever takes fundamental knowledge to decide if they want a biological weapon or a vaccine..." (Int. $\mathrm{N}^{\circ} 14$, intermediary profession, $1^{\text {st }}$ age bracket, control subject).

The question of responsibility arises all the more forcefully now that the participants have become aware that certain risks linked to their involvement in a human genome research project may turn out to be real. The ambiguity of the procedure is linked to the fact that it is presented as a tool for delivering information fully and thoroughly, in a situation where the information can only be partial and biased depending on the conclusion the participant has drawn. From then on, the scheme is potentially seen as investing the subject, who supposedly gave his 'informed' consent, with moral and ethical responsibilities that the subject says he does not wish to assume and, more importantly, that he says he cannot shoulder given his own knowledge of the project and the fact that he cannot possibly know the intentions of others. Although the written dimension of the consent makes individuals aware of the nature of the study in which they have agreed to participate, it also simultaneously leads them to question openly the quality of the information provided, which in turn leads them to fear that their ethical responsibility might be coupled with legal responsibility as well:

"What I mean is that when I sign and I read something, the least I can do is pay a little bit of attention because you never know what might happen next... maybe they'll want to take blood again, right? Now I don't know what you're going to do with my genes; what do I know... [...] In medicine there are things we know about and things we don't know about. Some people even want to set up sperm banks. Personally I've got nothing against it but, see, I for one wouldn't do it. I say! I wouldn't like to know that my children are walking around like that. Maybe there was a risk, who knows... I don't know... but DNA?... what's that?... they can't... the DNA is mine, it is my own, no one can use it... what do I know... what are they going to do with the DNA? Why take all these precautions? They made me sign that I agreed with all that, but why, I have no idea..." (Int. $\mathrm{N}^{\circ} 30$, Company worker, $3^{\text {rd }}$ age bracket, control subject). 


\section{Counter-intuitive asymmetry}

We have until now chiefly addressed disapproving points of view expressed by the participants about the consent procedure. The time has come to point out the existence of more consensual points of view that nonetheless show an underlying critical approach to the procedure. Quite surprisingly, certain participants brought to the fore the inability of our survey to provide 'decision-making clarification', given the individualized framework in which the consent was produced and that was part of the scheme itself. Thus, one of the participants interviewed confessed that he did not feel 'too well informed', but also pointed out that additional clarification might have been obtained through a meeting designed to inform and promote exchanges between the potential participants and the biomedical actors of the project. Far from criticizing the fact that such a meeting had not been set up in advance in order to help participants understand the ins and outs of the DNA bank project, he justified the absence of it. As a matter of fact, he seemed to think that it was sensible not to set up an information meeting, as the existing procedure seemed to generate higher rates of participation. Informing individuals collectively would doubtlessly increase the level of interaction between the biomedical team and the participants and would produce better informed decisions, but it might make a greater number of potential participants 'reluctant':

"Oh, I don't think I was well informed. What happened was, I was told to read the paper, and I did, sort of, and then... but anyway, I already knew a bit about those things, I could tell more or less what it was about. [...] Informed consent?... They would have had to call everybody, put them all together in a room and teach them for one hour. There. Then you can call yourself informed. But if you don't do that, if you just tell them "you know, look at that, hey, that's what you need to do and then that's it", well then the guy says yes, he tells you yes, but that doesn't mean he's very well informed (he laughs). That's right! You understand? If you take a course, then you're well-informed, "Does anybody have a question to ask?" Fine. That's informed. But you know what: I can see why they don't want to do things like that. -Interviewer: Why? -Interviewee: (silence) because... let me tell you, this is my own experience, the more you tell people, the more they go 'yes, but' and the more reluctant they get in the end. See? Because you make up your own mind naturally, and you say I'll do it. But then you're in a room, and everybody is saying 'of course, there is this and that, you know, there's that, there's that!' and you end up with a bunch of people saying: 'Well, after all, come to think of it, maybe there's some truth to it...' and blah blah blah, and when all's said and done, instead of having thirty people that go for it, you end up with twenty-five. Or twenty. So there. So for silly things like that it's not worth getting people to argue over nothing." (Int. $\mathrm{N}^{\circ} 44$, Shopkeeper, $3^{\text {rd }}$ age bracket, case subject).

These lines of reasoning show two dimensions of the issue that we believe are worth emphasizing. On the one hand, they indicate that in the context of individualized consentbuilding, underpinned by a procedure where the participants are called in one by one, the situation seems to foster cooperation, and the participants refrain from intervening actively in an exchange process. On the other hand, they point out that the existing scheme, being designed to call in one person at a time, seems to prevent individuals from using the resources that a group might offer when discussing participation and exposing 
the process involved. As we study the emic objectivation of the recruitment process and the collection of consent, their structure seems to generate a certain number of effects on decision-making and the nature of the act of cooperation involved. These effects, which are of a counter-intuitive nature insofar as the consent procedure is supposed to lead the individual to make an informed decision, might produce asymmetric power relations between the participant(s) and the actors of the DNA bank.

\section{Conclusions}

The patterns of interaction that we have observed, as well as the points of view of the participants recorded in interviews in many cases indicate that the frames of perception and interpretation of the actors have reached a raised level of awareness intended to detect the potential power asymmetry that might result from a scheme originally designed to provide information and grant their autonomy. The actors in the field of medical research regulation will find the elements in this study useful in planning the evolution of their research and design its practical ethical framework, particularly in the case of biobank projects. The informed consent procedure is not self-evident in the interactions that take place, since many of its users prefer to call into play different ways of keeping oneself at a distance ('quant-à-soi') to eschew the potential risks it could lead them to assume: 'avoidance' of the signing procedure, refusal to append their signature, pressing demands to the physician that he justifies this request, etc. Furthermore, the scheme may be criticized for its formal layout and the abusive interpretation of the physician/patient relationship that it seems to officialize by making it contractual. In the course of the interviews we found an explanation centred on two important issues. The first one is the diverse potential responsibilities that the participants identified and linked to their full involvement in the informed consent procedure. The second issue is the counter-intuitive asymmetry that might be generated by the individualized configuration of consentbuilding.

Our survey points out that research participants call upon their critical abilities in the application of the biopolitics of consent: they strive to detect any potential perverse effects and do not hold a fairy-tale vision of it even if they do not contest it radically. Their reactions and analyses, grounded or not, indicate caution in their assessment and a critical approach towards any form of constraint that might result from the contemporary implementation of biopolitics, and notably concerning the procedures for devolution of responsibilities highlighted in the literature over the past few years. These reactions show that the majority of the actors are inclined to adhere a priori to the current process of biopolitics. In this case, DNA 'donors' should not be viewed as disappointed by the institutional policy on the subject, which these days highlights the concept of user autonomy, information and participation. It is obvious that these critical points of view must not be seen solely as an agent retarding the progress of biobank projects, but also as a competency likely to prove useful to the development of such projects, which may provide the basis for a co-production process. $^{23}$

The question of the devolution of responsibilities and the reactions it may stir become all the more important since the context of the research which we have studied overlaps with a sphere of knowledge and action which is, for more than one reason, highly symbolic of the 'risk society' described by Bech (1992). The advances that enable

\footnotetext{
${ }^{23}$ For more about this topic, see chapter 9.
} 
us to explore the genomes, keep them in banks and preserve them and the potential applications of this line of research contribute to feed the 'anguished conscience' which seems to be the hallmark of the contemporary world of science and technology.

Therefore, the caution exercised by users when it comes to the new biopolitics is understandable given the 'anguished conscience' of the world. This state of mind may well be the reason why the actors involved in a procedure such as informed consent feel the need to preserve their 'quant-à-soi'. But this should not cause us to forget that the biopolitics of informed consent may also in turn play a role in building this conscience. In fact, it could well be that once confronted with the choice of what can and cannot be done with the body and its parts, put in a situation they never had to face before, the actors can only become more cautious, wary or even at times diffident when they consider the responsibilities with which they may be invested.

Acknowledgements: The authors wish to thank the research team members and the participants for observation and interviews. Useful discussions with Emmanuelle RialSebbag, Pierre Antoine Gourraud and Jacques Lefrançois are gratefully acknowledged. This work was performed with the financial support of the project 'Mapping the language of Research Biobanking' (Contract No. 159864/S10.) of the Norwegian Research Council and the Norwegian Institute of Public Health, the project 'Research biobanking and the ethics of transparent communication' (Contract No 182269 ) of the Norwegian Research Council, the FP6 EU Coordination Action PHOEBE (Contract No. LSHG-CT-2006518148) and an Incitative Concerted Action "Internationalisation of HSS" (No. 042 533), GenPos (Human population genetics and public health: multidisciplinary analysis and international comparison of the normative contexts and practices) of the French Ministry for National Education, Higher Education and Research.

\section{References}

Beck U (1992) Risk Society: Towards a New Modernity. Sage, New Delhi

Benveniste E (1969) Le vocabulaire des institutions européennes, tome 1 : économie, parenté, société. Editions de Minuit, Paris

Bungener M et al. (2002) Quelle médecine voulons-nous ?. La dispute, Paris

Cambon-Thomsen A et al. (2007) Trends in ethical and legal frameworks for the use of human biobanks. Eur Respir J 30: 373-382

Caze De Mongolfier S (2002) Collecte, stockage et utilisation des produits du corps humain dans le cadre des recherches en génétique: états des lieux, historique, éthique et juridique. Ph.D. thesis, Université René Descartes, Faculté de médecine de Necker-Paris

Dozon JP (2001) Quatre modèles de prévention. In : Dozon JP, Fassin D (Eds.) Critique de la santé publique. Une approche anthropologique. Balland, Paris, pp 23-46

Foucault M (1976) La volonté de savoir. Gallimard, Paris 
Foucault M (1994) La politique de santé au XVIIIème siècle. In : Dits et écrits. Gallimard, Paris, pp 13-27

Goffman E (1974) Les rites d'interaction. Editions de Minuit, Paris

HUGO-ELSI Committee (1995) Statement on the principled conduct of genetics research. Eubios J Asian Int Bioethics 6: 59-60

Karpik L (1996) Dispositifs de confiance et engagements crédibles. Sociologie du travail 4:527549

Martuccelli D (2004) Figures de la domination. Revue Française de Sociologie, 45:469-497

Memmi D (2001) Surveiller les corps aujourd'hui: un dispositif en mutation?. In: Sfez L (Ed.) L'utopie de la santé parfaite. Presses Universitaires de France, Paris, pp 173-184

Memmi D (2003) Faire vivre et laisser mourir: le gouvernement contemporain de la naissance et de la mort. La Découverte, Paris

Michael M (1996) Ignoring Science: discourses of ignorance in the public understanding of science. In: Wynne B, Irwin A (Eds.) Misunderstanding Science? The public Reconstruction of Science and Technology. Cambridge University Press, Cambridge, pp 107-125

Moulin AM (2000) Les sociétés au siècle de la santé. Médecine/sciences 11:1186-1191

Moutel G (2003) Le consentement dans les pratiques de soins et de recherche en médecine. Entre idéalismes et réalités cliniques. L'Harmattan, Paris

Polton D (2000) Quel système de santé à l'horizon 2020? (Rapport préparatoire au schéma de services collectifs sanitaires). La Documentation française, Paris 